\title{
A RARE PHENOMENON CREATING DILEMMA FOR THE SURGEON: PNEUMOPERITONEUM AFTER COLONOSCOPY
}

\author{
Ferhatoglu Ferhat Murat, Filiz Ilker Ali \\ Okan University, Faculty of Medicine, Department of General Surgery, Istanbul, Turkey
}

Primljen/Received 23. 07. 2018. god.

Abstract: Pneumoperitoneum is free air existence in abdomen and usually caused by the perforation in gastrointestinal system. Peptic ulcer disease is the most common cause of perforation and pneumoperitoneum. The presence of free air in abdomen usually indicates emergency surgery. However, surgical approach is not required in some cases of pneumoperitoneum if there is no evidence of perforation and no sign of peritoneal irritation. Herein, we present an 82-year-old male patient who had pneumoperitoneum after colonoscopy and treated non-surgically.

Key words: colonoscopy, complication, pneumoperitoneum.

\section{INTRODUCTION}

Colonoscopy is known as a safe procedure, but complications may occur. The most common complications are perforation and massive haemorrhage (1). The incidence of these serious complications is low but, despite increased experience with the procedure, it remains unchanged over time. The risk for adverse events has been also associated with comorbidity: diabetes mellitus, history of previous stroke or cardiovascular disease, chronic obstructive pulmonary disease. But pneumoperitoneum without sings of peritonitis after colonoscopy is a rare phenomenon which creates a management dilemma for the surgeon (2). Herein, we present an 82-year-old male patient who had pneumoperitoneum after colonoscopy and treated non-surgically.

\section{CASE PRESENTATION}

An 82-year-old, Jordanian male with a history of hypertension and oesophagus carcinoma surgery 14 months ago was undergoing routine upper gastrointestinal system endoscopy and colonoscopy with sedoanalgesia. Both procedures complicated uneventfully and no pathologies were found. Two hours after endoscopic
Prihvaćen/Accepted 05. 08. 2018. god.

procedures, he complained about abdominal and shoulder pain. On examination, the patient's blood pressure was $155 / 90 \mathrm{~mm} \mathrm{Hg}$, heart rate was $72 \mathrm{bpm}$ and body temperature was $37.2{ }^{\circ} \mathrm{C}$. His abdominal examination did not reveal any signs of rigidity or rebound but abdomen was distended and tympanic by percussion. Complete blood count revealed a white blood count of 4550 cells $/ \mathrm{mm}^{3}\left(4600-10200\right.$ cells $\left./ \mathrm{mm}^{3}\right)$ and haematocrit level of $36 \%(40 \%-54 \%)$. His electrolytes, liver function tests, blood urea nitrogen and creatinine were normal. Intravenous and oral contrast-enhanced computed tomography scan revealed only pneumoperitoneum (Figure 1). Non-surgical treatment decision was taken due to the fact that the patient has no sign of acute abdomen, no fever, his leukocyte value was normal, and there was no free fluid in the computed tomography. His oral diet was stopped, intravenous fluid and $2^{\text {nd }}$ generation cephalosporin antibiotics started as a precaution. On the third day of his follow up, his complains about abdominal and shoulder pain decreased also body temperature was 36.8 ${ }^{\circ} \mathrm{C}$. on his examination, his abdominal distension and

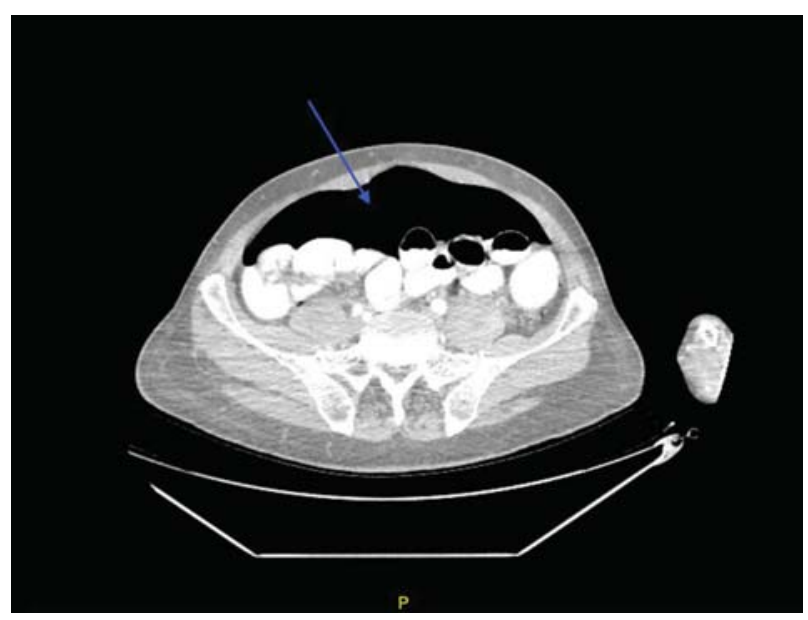

Figure 1. Computed tomography image of pneumoperitoneum (Blue arrow) 
tympanic sound by percussion decreased. His bowel sounds were normoactive and he had defecation. Complete blood count revealed a white blood count of 6500 cells $/ \mathrm{mm}^{3}$. He was started on an oral liquid diet on the third day and given a normal salt-free diet on the fourth day. During the period of hospitalisation, his vital signs were normal. The patient stayed in hospital for 7 days. The patient was discharged without any problem.

\section{DISCUSSION}

Colonoscopy is a safe and effective examination technique for visualization of colonic lumen and it is commonly used to diagnose colonic pathologies and nowadays, it is used for treating some pathologies. The literature reports a complication rate of up to $0.5 \%$ (1). Most common complications of colonoscopy including perforation and massive haemorrhage are rare but have potential to cause very serious consequences even lead to fatal outcome. Direct mechanical trauma of colonoscopy, thermal trauma from electrocautery of laser device and barotrauma from excessive air insufflation are mechanisms of colonoscopy related perforation (2) which has prevalence ranges from $0.016 \%$ to $0.2 \%$ following diagnostic examination and up to $5 \%$ after therapeutic colonoscopy (3). Polypectomy, pneumatic di-

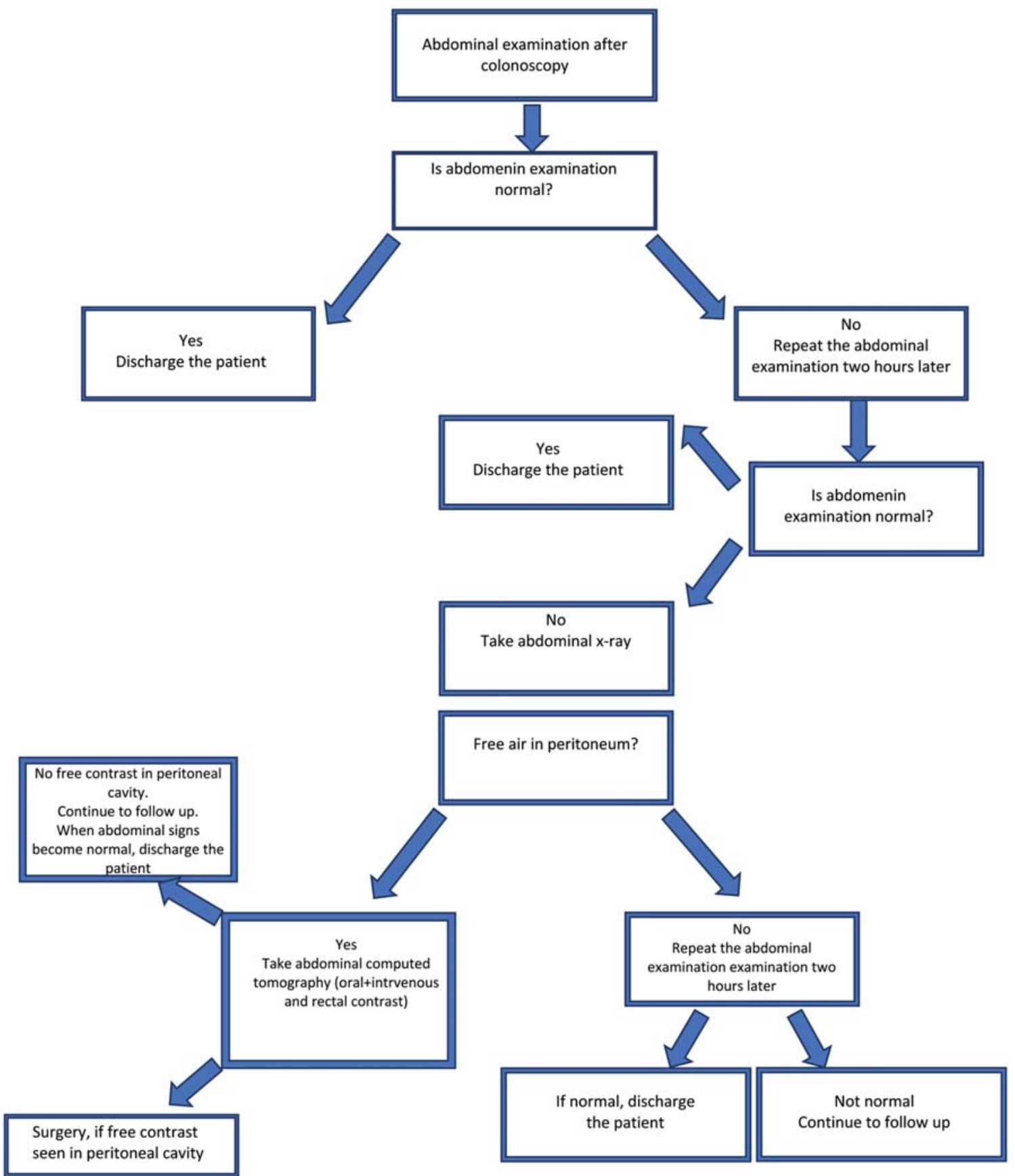

Figure 2. Algorthym of management free peritoneal air after colonoscopy 
latation for Chron stricture, mucosal resection of lesions during colonoscopy are high risk procedures. Patients older than 75 years or those with comorbid diseases also have increased risk of perforation (4). After colonoscopy, patients usually describe abdominal and shoulder pain from referred diaphragmatic irritation. Physical examination may reveal a distended, rigid abdomen which is tympanic by percussion. Intestinal sounds may be hypoactive or absent. Abdominal tenderness varies and is present due to peritoneal irritation. Subcutaneous air and crepitation in the abdominal wall may be present. Increase of abdominal pressure may causes upward distension of diaphragm muscle which leads to respiratory problems (3). Pneumoperitoneum without sings of peritonitis after colonoscopy is a rare phenomennon which creates a management dilemma for the surgeon. Pneumoperitoneum may occur without perforation. Colonic mucosa may become air permeable if mucosa is herniated via muscular layer and serosa (5). In contrast with this hypothesis, $2 n$ the study of Pearl JP et al, 100 patients underwent colonoscopy and then radiography of the chest and abdomen to detect free air. They revealed, no cases of benign pneumoperitoneum were detected and they argued pneumoperitoneum after colonoscopy is possibly non-existent and advocated to treat all cases of free in- traabdominal air after colonoscopy as perforations (6). Other causes of pneumoperitoneum are emphysematous cholecystitis (7), spontaneous bacterial peritonitis (8), intestinal cystic pneumatosis (9), and liver abscess (10). Most common gynecological cause is rupture of pyometra (11). As a result of this rare condition and management dilemma, some of these patients may underwent unnecessary laparotomy (Figure 2).

\section{CONCLUSION}

Pneumoperitoneum after colonoscopy is a rare and unusual situation which creates a dilemma for the surgeon. We think that patients can be followed without surgery if there is no free fluid and no evidence of acute abdomen despite free air.

\section{DECLARATION OF INTEREST}

The autors declare that there are no conflicts of interests.

\section{Licensing}

This work is licensed under a Creative Commons Attribution 4.0 International (CC BY 4.0) License.

\title{
Sažetak
}

\section{REDAK FENOMEN KAO DILEMAZA HIRURGA: PNEUMOPERITONEUM NAKON KOLONOSKOPIJE}

\author{
Ferhatoglu Ferhat Murat, Filiz Ilker Ali \\ Okan University, Faculty of Medicine, Department of General Surgery, Istanbul, Turkey
}

Pneumoperitoneum je prisustvo slobodnog vazduha u trbuhu i obično je uzrokovan perforacijom u gastrointestinalnom sistemu. Peptički ulkus je najčešci uzrok perforacije i pneumoperitoneuma. Prisustvo slobodnog vazduha u trbuhu je obično indikacija za hitnu operaciju. Ipak, hirurški tretman nije neopho-

\section{REFERENCES}

1. Levin TR, Zhao W, Conell C, Seeff LC, Manninen DL, Shapiro JA, et al. Complications of colonoscopy in an integrated health care delivery system. Ann Intern Med. 2006; 145(12): 880-6.

2. Gupta A, Zaidi H, Habib K. Pneumothorax after colonoscopy - a review of literature. Clin Endosc. 2017; 50(5): 446-50.

3. Carey JL, Napoli AM. Tension pneumoperitoneum during routine colonoscopy. Am J Emerg Med. 2012; 30(1): 261-2.

4. Arora G, Mannalithara A, Singh G, Gerson LB, Triadafilopoulos G. Risk of perforation from a colonoscopy in adults: a dan u nekim slučajevima pneumoperitoneuma, i to ukoliko ne postoji dokaz o perforaciji i ukoliko nema znakova iritacije peritoneuma. Predstavljamo pacijenta muškog pola, starog 82 godine, koji je imao pneumoperitoneum nakon kolonoskopije i nije lečen hirurški.

large population based study. Gastrointest Endosc. 2009; 69(3Pt2): 654-64.

5. Nwashilli $\mathrm{Nj}$, Irowa O, Ohanaka EC. Pneumaperitoneum, pneumomediastinum, pneumopericardium and subcutaneous emphysema following colonoscopy-a case report. Ann Biomed Sci. 2016; 15(1): 23-7.

6. Pearl JP, McNally MP, Elster EA, De Nobile JW. Benign pneumoperitoneum after colonoscopy: a prospective pilot study. Mil Med. 2006; 171(7): 648-9.

7. Modini C, Clementi I, Simonelli L, Antoniozzi A, Assenza M, Ciccarone F, et al. Acute emphysematous cholecysti- 
tis as a cause of pneumoperitoneum. Chir Ital. 2008; 60(2): $315-8$.

8. Lai FC, Wu CC, Hwu DH, Liu TJ, P'eng FK. Pneumoperitoneum caused by spontaneous bacterial peritonitis: a case report. Zhonghua Yi Xue Za Zhi (Taipei). 1994; 54(5): 373-5.

9. Yamana I, Noritomi T, Takeno S, Tatsuya H, Sato K, Shimaoka H, et al. Spontaneous Pneumoperitoneum due to Constipation. Case Rep Gastroenterol. 2015; 9(3): 361-5.
10. Kim JH, Jung ES, Jeong SH, Kim JS, Ku YS, Hahm $\mathrm{KB}$, et al. A case of emphysematous hepatitis with spontaneous pneumoperitoneum in a patient with hilar cholangiocarcinoma. Korean J Hepatol. 2012; 18(1): 94-7.

11. Shapey IM, Nasser T, Dickens P, Haldar M, Solkar MH. Spontaneously perforated pyometra: an unusual cause of acute abdomen and pneumoperitoneum. Ann R Coll Surg Engl. 2012; 94(8): 246-8.

\section{Correspondence to / Autor za korespondenciju}

M. Ferhat Ferhatoglu, M.D.

Department of General Surgery

Okan University, Faculty of Medicine, Istanbul, Turkey

E-mail: ferhatferhatoglu@yahoo.co.uk

Phone number: +905553214793

Address: Aydinli yolu caddesi, Okan Üniversitesi Hastanesi, Tuzla, Istanbul, Turkey 